\title{
Investigation the Natural Radioactivity in Local and Imported Chemical Fertilizers
}

\author{
Raad Obid Hussain and Hayder Hamza Hussain* \\ Physics Department; College of science; Kufa University; Najaf - Iraq
}

\begin{abstract}
In order to assess the radioactive level in the environment, the specific activities of ${ }^{238} U,{ }^{232} \mathrm{Th}$ and ${ }^{40} \mathrm{~K}$ were measured by using a gamma ray spectrometer based on a NaI(Tl) detector. The results showed that the specific activities of ${ }^{238} \mathrm{U},{ }^{232} \mathrm{Th}$ and ${ }^{40} \mathrm{~K}$ were $12.846-88.585,1.304-26.656$ and $11.598-2275.896 \mathrm{~Bq} / \mathrm{kg}$ respectively. The radium equivalent activity was also calculated which varied from 0.893 to $175.244 \mathrm{~Bq} / \mathrm{kg}$. The radium equivalent average values were lower than the world average. In general, the highest level of radium equivalent value was in leafy type NPK fertilizers. The urea type had no radionuclide. The specific activity and absorbed dose rate at $1 \mathrm{~m}$ above the ground surface $(n G y / h)$ after NPK fertilizers agricultural applications were calculated and the maximum value of dose rate was $0.15 \%$ of the world average outdoor exposure due to terrestrial gamma radiation.
\end{abstract}

Key words: Natural radioactivity, Gamma-spectrometry, Fertilizers

\section{INTRODUCTION}

In the last 20 years the Iraqi agriculture would not have been possible without the application of large quantity of fertilizers. Modern agriculture applies high technology aiming at increasing the productivity. The Public and farmers are exposed to ionizing radiation from the radionuclides that are present in different types of natural sources of which chemical fertilizers (NPK, Nitrogen, Phosphore and Potassium) are one of the most important sources. The granular type fertilizers are applied directly on the soil in which they dissolve slowly in the irrigation water whereas the leafy types (powder form) are dissolved in water that is sprayed over the leaves.

Phosphate is used in the production of some chemical fertilizers. Since phosphate contains some natural radionuclides like ${ }^{238} \mathrm{U},{ }^{232} \mathrm{Th}$ and
${ }^{40} \mathrm{~K}$, fertilizers become the major contributor for outdoor terrestrial natural radiations. The phosphate material is very insoluble, and therefore, in its original state is practically unavailable as a plant phosphors source (IAEA, 1973). Among the constituents of agricultural phosphate fertilizers are potassium ores (potassium sulphate, potassium chloride) (Conceição and Bonotto, 2006).

Investigation of gamma activity in the chemical fertilizers, has been performed in order to determine the effect of the use of chemical fertilizers on human health. A possible negative effect of chemical fertilizers is contaminating the cultivated hands by trace metals and some naturally occurring radioactive materials (NORM) (Lambert et al., 2007). Radionuclides present in phosphate fertilizers affect the common people and farmers immensely (Ghosh et al, 2008). The

*Author for correspondence: hyder_ham@yahoo.com 
large concentration of natural radionuclides in the fertilizers contaminates the environment and agricultural field. Direct inhalation of dust of phosphate fertilizers could affect the farmers on agricultural land (Pfister et al, 1976; Scholten and Timmermans, 1996).

Exposure to ionizing radiation is generally considered undesirable at all level. The energy of gamma emitted from ${ }^{238} \mathrm{U},{ }^{232} \mathrm{Th}$ and ${ }^{40} \mathrm{~K}$ is greater than $1.022 \mathrm{MeV}$ which is the threshold of pair production (electron-positron). So the dangerous damage of this kind of radiation must be taken into count. Chemical fertilizers are considered one of a great additive of natural radionuclides, especially ${ }^{40} \mathrm{~K}$ in the environment. Potassium is in the human bodies is mostly acquired through the ingestion of food, which irradiates the cells. The natural ionizing radiation represents $10 \%$ of the average annual dose to the human body from all types of radiation (UNSCEAR, 1993). The environmental impact of chemical fertilizer production depends on the raw materials, production processes and the status of the pollution control equipment (Bhatti and Malik, 1994). Exposure of workers and the public to radiation from fertilizers is, therefore, not unlikely (Diab et al, 2008). Higher radiation levels are associated with the chemical fertilizers, therefore, the study of natural activity in artificial fertilizers are of a great interest in environmental pollution field. This is first such study conducted in Iraq. The main objectives of the study were to qualify and quantify the presence of natural radionuclides in the chemical fertilizers available in the local markets as well as to draw the radiological baseline information of these fertilizers in Iraq.

\section{EXPERIMENTAL PROCEDURE}

\section{Sampling and activity measurement}

A total of 16 chemical fertilizer samples (10 NPK granular type, four NPK leafy type and two urea type) were collected from the local markets of four different provinces (Babylon, Karbala, Najaf and Qadisiya) in Iraq. Two of these samples were Iraqi production (local fertilizer) whereas the rest were imported by the Iraqi governorate. Each sample represented the average of four samples for each type. Every sample was crushed, oven dried at 100 $\mathrm{C}^{\mathrm{o}}$ for $24 \mathrm{~h}$ and meshed perfectly to pass through $0.2 \mathrm{~mm}$ mesh. One kilogram from each sample was packed and sealed in a marinelli beaker of one liter. The measurements were performed five weeks later to ensure the secular equilibrium (Hamby and Tynybekov, 2002; Vassas et al, 2006; El-Zakla et al, 2007).

The specific activities were performed by gamma rays spectrometry, employing a $\mathrm{NaI}(\mathrm{Tl})$ (BICRON) of $2 " \times 2 "$ crystal dimensions detector housed in a lead castle and coupled with 4096 channel analyzer of CASSY type. The resolution of the system was of 6.73 for the $0.662 \mathrm{MeV}{ }^{137} \mathrm{Cs}$ photopeak. The counting efficiency of the system was measured by using standard sources $\left({ }^{22} \mathrm{Na}\right.$, ${ }^{57} \mathrm{Co},{ }^{60} \mathrm{Co},{ }^{109} \mathrm{Cd},{ }^{133} \mathrm{Ba}$ and ${ }^{137} \mathrm{Cs}$ ), where was $3.5 \%$ for $1.332 \mathrm{MeV}$ of ${ }^{60} \mathrm{Co}$. Uranium-238 was detected by the $1.76 \mathrm{MeV}$ energy that corresponded to the absorption of ${ }^{214} \mathrm{Bi}$ of ${ }^{238} \mathrm{U}$ series and used to identify and quantify the natural uranium. Natural thorium-232 was identified by the ${ }^{208} \mathrm{Tl}$ peak which corresponded to the 2.62 $\mathrm{MeV}$ absorption energy (Becegato, 2008). Potassium-40 was identified and quantified by means of the absorption of the $1.46 \mathrm{MeV}$ energy which corresponded to a sole natural isotope ${ }^{40} \mathrm{~K}$. In order to subtract the background from each measurement, an empty marinelli beaker (with the same geometry) was measured. The accumulation time for each sample was 10000 s just to obtain gamma spectrum with appropriate to the detector statistics.

The specific activity of radionuclides were calculated using the following equation (Singh et al, 2009):

$\left(\begin{array}{c}\text { Specific } \\ \text { Activity }\end{array}\right)=\frac{\mathrm{CPS} \times 100 \times 100}{\mathrm{Eff} \times \text { B.I. } \times \mathrm{m}} \pm \frac{\mathrm{SD}_{\mathrm{CPS}} \times 100 \times 100}{\mathrm{Eff} \times \text { B.I. } \times \mathrm{m}}$

Where, CPS $=$ Net count rate per second, B.I. = Branching Intensity, Eff = Efficiency of the detector, $\mathrm{m}=$ Sample mass in $\mathrm{kg}$ and $\mathrm{SD}_{\mathrm{CPS}}=$ Standard Deviation of net count rate per second.

\section{Radium equivalent activity}

From the radiation point of view, the high content of fertilizers was significant in the accumulation of large quantities of chemical fertilizers in the warehouse, which increased the Radon concentration in the surrounding air. The widely used radiation hazard index $\mathrm{Ra}_{\mathrm{eq}}$ is called the radium equivalent activity; the radiation equivalent activity is a weight sum of activities of the three natural radionuclides ${ }^{238} \mathrm{U},{ }^{232} \mathrm{Th}$ and ${ }^{40} \mathrm{~K}$ based on 
the estimation that $10 \mathrm{~Bq} / \mathrm{kg}$ of ${ }^{226} \mathrm{Ra}, 7 \mathrm{~Bq} / \mathrm{kg}$ of ${ }^{232} \mathrm{Th}$ and $130 \mathrm{~Bq} / \mathrm{kg}$ of ${ }^{40} \mathrm{~K}$ produce the same gamma ray dose rate (Beretka and Matthew, 1985). The radium equivalent activity was calculated by using the following relation.

$\mathrm{Ra}_{\mathrm{eq}}=\mathrm{C}_{\mathrm{U}}+1.43 \mathrm{C}_{\mathrm{Th}}+0.077 \mathrm{C}_{\mathrm{K}}$

Where $\mathrm{C}_{\mathrm{U}}, \mathrm{C}_{\mathrm{Th}}$ and $\mathrm{C}_{\mathrm{K}}$ are the specific activities of ${ }^{238} \mathrm{U},{ }^{232} \mathrm{Th}$ and ${ }^{40} \mathrm{~K}$ in $(\mathrm{Bq} / \mathrm{kg})$ unit respectively.

\section{RESULTS AND DISCUSSION}

The spectra of 16 chemical fertilizers samples were analyzed. The results of specific activities of ${ }^{238} \mathrm{U},{ }^{232} \mathrm{Th}$ and ${ }^{40} \mathrm{~K}$ and radium equivalent activity $\left(\mathrm{Ra}_{\mathrm{eq}}\right)$ in different samples (10 NPK granular types, four NPK leafy types and two urea types) are presented in Table 1 . For ${ }^{238} \mathrm{U}$ radionuclide, only four samples (NPK1, NPK6, NPK9 and NPK10) had specific activities values of (12.846, $143.154,88.585$ and $13.873 \mathrm{~Bq} / \mathrm{kg}$, respectively). The values for NPK6 and NPK9 were higher than the world average of $41 \mathrm{~Bq} / \mathrm{kg}$ (UNSCEAR, 1983). The ${ }^{238} U$ specific activity in the local granular NPK fertilizer sample (NPK6) was much higher than that in the imported granular and leafy samples. Such result could be explained in a high concentration of ${ }^{238} \mathrm{U}$ in the Iraqi Phosphate rocks which was used widely as raw material for manufacturing the NPK chemical fertilizers. Of the 16 samples, only five samples (NPK1, NPK6, NPK8, NPK9 and NPK10) showed thorium with specific activities of 1.304, 16.223, 26.656, 2.582 and $2.817 \mathrm{~Bq} / \mathrm{kg}$ respectively, which were less than the world average of $52.2 \mathrm{~Bq} / \mathrm{kg}$ (UNSCEAR, 1983).

The ${ }^{40} \mathrm{~K}$ radionuclide was present in all the NPK samples, except NPK5. The highest value of $2775.896 \mathrm{~Bq} / \mathrm{kg}$ was in NPK13 sample, while the lowest value of $11.598 \mathrm{~Bq} / \mathrm{kg}$ was in NPK2 sample. Table 1 indicated that the specific activities of ${ }^{40} \mathrm{~K}$ radionuclides in leafy NPK fertilizer types were higher than that in the granular NPK fertilizer (as shown in Fig. 1). These values, except five, were also higher than the world average which was $230 \mathrm{~Bq} / \mathrm{kg}$ for (UNSCEAR, 1983). The NPK5 sample had no activity detected due to the lack of concentrations of radionuclides in its raw materials. For urea samples, no activity was found in urea fertilizers because their the ores did not contain natural radionuclides.

Table 1 - Specific activities of ${ }^{238} \mathrm{U},{ }^{232} \mathrm{Th}$ and ${ }^{40} \mathrm{~K}$ and radium equivalent activity $(\mathrm{Bq} / \mathrm{kg}$ ) in NPK and Urea fertilizers.

\begin{tabular}{|c|c|c|c|c|c|}
\hline Type & Sample & U-238 & Th-232 & K-40 & $\mathbf{R a}_{\mathrm{eq}}$ \\
\hline \multirow[t]{12}{*}{ Granule Fertilizers } & $\mathrm{NPK} 1^{\mathrm{a}}$ & $12.846 \pm 1.149$ & $1.304 \pm 0.184$ & $770.859 \pm 10.196$ & $74.067 \pm 2.198$ \\
\hline & NPK2 ${ }^{a}$ & $<\mathrm{DL}^{*}$ & $<\mathrm{DL}$ & $11.598 \pm 1.251$ & $0.893 \pm 0.096$ \\
\hline & NPK $3^{a}$ & $<\mathrm{DL}$ & $<\mathrm{DL}$ & $12.542 \pm 1.301$ & $0.966 \pm 0.100$ \\
\hline & NPK4 ${ }^{\mathrm{a}}$ & $<\mathrm{DL}$ & $<\mathrm{DL}$ & $112.743 \pm 3.899$ & $8.681 \pm 0.300$ \\
\hline & NPK5 ${ }^{a}$ & $<\mathrm{DL}$ & $<\mathrm{DL}$ & $<\mathrm{DL}$ & $<\mathrm{DL}$ \\
\hline & NPK6 ${ }^{\mathrm{b}}$ & $143.154 \pm 3.836$ & $16.223 \pm 0.650$ & $93.458 \pm 3.550$ & $173.549 \pm 5.039$ \\
\hline & NPK $7^{\text {a }}$ & $<\mathrm{DL}$ & $<\mathrm{DL}$ & $733.638 \pm 9.947$ & $56.490 \pm 0.766$ \\
\hline & NPK8 ${ }^{a}$ & $<\mathrm{DL}$ & $26.656 \pm 0.834$ & $112.473 \pm 3.895$ & $46.779 \pm 1.492$ \\
\hline & NPK9 $^{a}$ & $88.585 \pm 3.017$ & $2.582 \pm 0.260$ & $741.999 \pm 10.003$ & $149.411 \pm 4.159$ \\
\hline & NPK10 ${ }^{a}$ & $13.873 \pm 1.194$ & $2.817 \pm 0.271$ & $887.648 \pm 10.940$ & $86.251 \pm 2.424$ \\
\hline & UREA $1^{\mathrm{a}}$ & $<\mathrm{DL}$ & $<\mathrm{DL}$ & $<\mathrm{DL}$ & $<\mathrm{DL}$ \\
\hline & UREA $2^{b}$ & $<\mathrm{DL}$ & $<\mathrm{DL}$ & $<\mathrm{DL}$ & $<\mathrm{DL}$ \\
\hline \multirow[t]{4}{*}{ Leafy Fertilizers } & NPK11 ${ }^{a}$ & $<\mathrm{DL}$ & $<\mathrm{DL}$ & $2183.383 \pm 17.160$ & $168.120 \pm 1.321$ \\
\hline & NPK12a & $<\mathrm{DL}$ & $<\mathrm{DL}$ & $1730.793 \pm 15.278$ & $133.271 \pm 1.176$ \\
\hline & NPK13 ${ }^{a}$ & $<\mathrm{DL}$ & $<\mathrm{DL}$ & $2275.896 \pm 17.519$ & $175.244 \pm 1.349$ \\
\hline & NPK14 ${ }^{a}$ & $<\mathrm{DL}$ & $<\mathrm{DL}$ & $1077.936 \pm 12.057$ & $83.001 \pm 0.928$ \\
\hline
\end{tabular}

\footnotetext{
*DL: detection limit, $2.8,1.16$ and $6.0 \mathrm{~Bq} / \mathrm{kg}$ for ${ }^{238} \mathrm{U},{ }^{232} \mathrm{Th}$ and ${ }^{40} \mathrm{~K}$ respectively.

a imported fertilizer

${ }^{\mathrm{b}}$ local fertilizer
} 


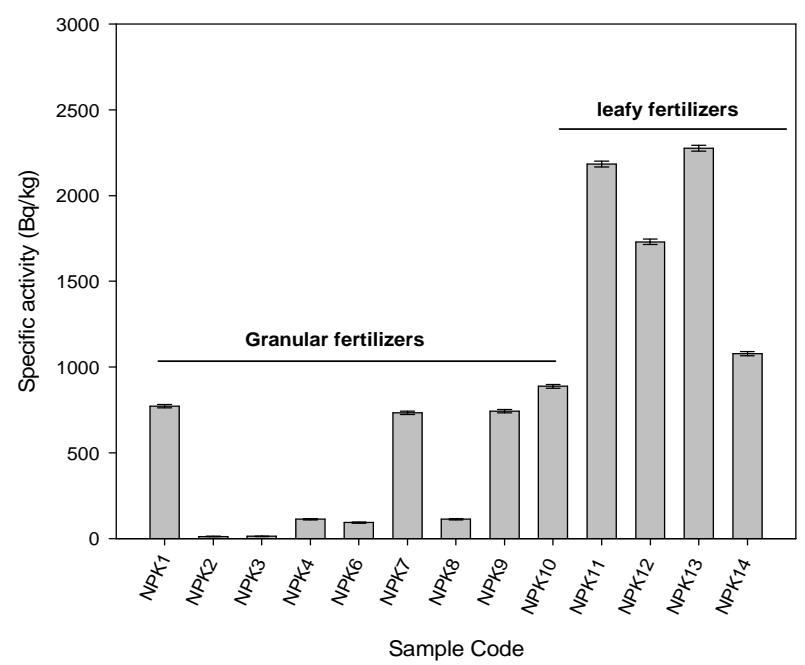

Figure 1 - Specific activities of ${ }^{40} \mathrm{~K}(\mathrm{~Bq} / \mathrm{kg})$ in NPK granular and leafy fertilizers.

Table 1 showed that the radium equivalent activity in the investigated samples ranged from 0.893 $\mathrm{Bq} / \mathrm{kg}$ in NPK2 to $175.244 \mathrm{~Bq} / \mathrm{kg}$ in NPK13 sample. The highest radium equivalent activity value was less than the world average (UNSCEAR, 2000) by about two times. In general, radium equivalent activity in the leafy NPK fertilizers was higher than that in the granular NPK fertilizer (Fig. 2). This difference in radium equivalent was due to the high content of ${ }^{40} \mathrm{~K}$.

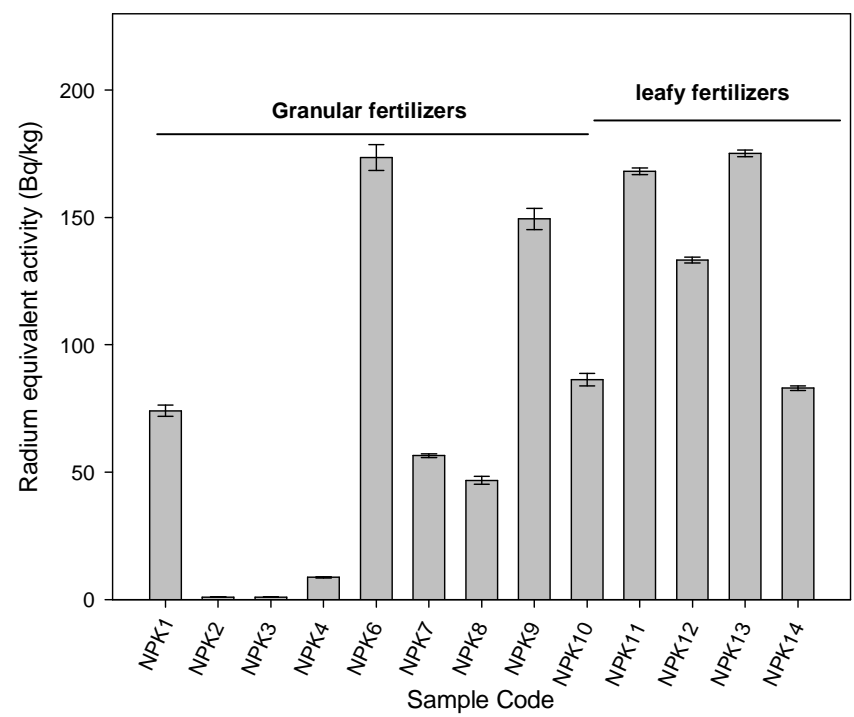

Figure 2 - Radium equivalent activity $(\mathrm{Bq} / \mathrm{kg})$ for NPK granular and leafy fertilizers.

The external exposure due to radionuclides in the chemical fertilizers used in the agricultural area was proportional to the intensity of fertilizers application. The application rate of chemical fertilizers (NPK type) was about of $600 \mathrm{~kg} / \mathrm{ha}$ in a year (Conceição and Bonotto, 2006). Based on this average application rate, the annual addition of natural specific activities distributed per unit area and mass $\left(\mathrm{Bq} / \mathrm{m}^{2}\right.$ and $\mathrm{Bq} / \mathrm{kg}$ ) corresponded to 0.771-8.589, 0.078-1.599 and 0.696-136.554 $\mathrm{Bq} / \mathrm{m}^{2}$ and $0.010-0.115,0.001-0.021$ and 0.009 $1.821 \mathrm{~Bq} / \mathrm{kg}$ for ${ }^{238} \mathrm{U},{ }^{232} \mathrm{Th}$ and ${ }^{40} \mathrm{~K}$, respectively (Table 2). 
The increase in the external radiation exposure due to the application of granule and phosphate fertilizers ranged from 0.00039 to $0.07592 \mathrm{nGy} / \mathrm{h}$ (Fig. 3). The maximum value represented $0.15 \%$ of the world average outdoor exposure due to terrestrial gamma radiation $(51 \mathrm{nGy} / \mathrm{h})$ (UNSCEAR, 2000).

The results showed a wide variation in gamma activity in NPK fertilizers. This could be attributed due to the followings:

1. The difference in the factories of manufactured fertilizers.

2. The difference in the places from which the raw minerals for manufacturing the fertilizers were taken.

3. Raw materials contained radioactive elements different properties depending on local geology.

Table 2 - Annual additional increment $\left(\mathrm{Bq} / \mathrm{m}^{2}\right.$ and $\left.\mathrm{Bq} / \mathrm{kg}\right)$ of ${ }^{238} \mathrm{U},{ }^{232} \mathrm{Th}$ and ${ }^{40} \mathrm{~K}$, and calculated absorbed dose rate $1 \mathrm{~m}$ above the ground surface $(\mathrm{nGy} / \mathrm{h})$ originated from NPK fertilizers agricultural applications.

\begin{tabular}{|c|c|c|c|c|c|c|c|}
\hline \multirow{2}{*}{$\begin{array}{l}\text { Sample } \\
\text { Code }\end{array}$} & \multicolumn{3}{|c|}{ Surface activity $\left(\mathrm{Bq} / \mathrm{m}^{2}\right)^{\mathrm{a}}$} & \multicolumn{3}{|c|}{ Specific Activity (Bq/kg) } & \multirow{2}{*}{$\begin{array}{l}\text { Dose rate } \\
(\mathrm{nGy} / \mathrm{h})^{\mathrm{c}}\end{array}$} \\
\hline & U-238 & Th-232 & K-40 & U-232 & Th-232 & K-40 & \\
\hline NPK1 & 0.771 & 0.078 & 46.252 & 0.010 & 0.001 & 0.617 & 0.03109 \\
\hline NPK2 & - & - & 0.696 & - & - & 0.009 & 0.00039 \\
\hline NPK3 & - & - & 0.753 & - & - & 0.010 & 0.00042 \\
\hline NPK4 & - & - & 6.765 & - & - & 0.090 & 0.00376 \\
\hline NPK5 & - & - & - & - & - & - & - \\
\hline NPK6 & 8.589 & 0.973 & 5.607 & 0.115 & 0.013 & 0.075 & 0.06387 \\
\hline NPK7 & - & - & 44.018 & - & - & 0.587 & 0.02447 \\
\hline NPK8 & - & 1.599 & 6.748 & - & 0.021 & 0.090 & 0.01663 \\
\hline NPK9 & 5.315 & 0.155 & 44.520 & 0.071 & 0.002 & 0.594 & 0.05874 \\
\hline NPK10 & 0.832 & 0.169 & 53.259 & 0.011 & 0.002 & 0.710 & 0.03610 \\
\hline UREA1 & - & - & - & - & - & - & - \\
\hline UREA2 & - & - & - & - & - & - & - \\
\hline NPK11 & - & - & 131.003 & - & - & 1.747 & 0.07284 \\
\hline NPK12 & - & - & 103.848 & - & - & 1.385 & 0.05774 \\
\hline NPK13 & - & - & 136.554 & - & - & 1.821 & 0.07592 \\
\hline NPK14 & - & - & 64.676 & - & - & 0.862 & 0.03596 \\
\hline
\end{tabular}

${ }^{\mathrm{a}}$ Based on the addition of $600 \mathrm{~kg}$ fertilizer/ha $\left(10000 \mathrm{~m}^{2}\right)$.

${ }^{\mathrm{b}} \mathrm{In}$ the top $5 \mathrm{~cm}$ of the soil that has average density value of 1.5 (75 kg soil weight per $0.05 \mathrm{~m}^{3}$ volume).

${ }^{\mathrm{c}}$ Estimated using dose rate conversion factors $(\mathrm{DRCF})=0.462,0.604$ and $0.0417 \mathrm{nGy} / \mathrm{h}$ per Bq/kg to ${ }^{238} \mathrm{U},{ }^{232} \mathrm{Th}$ and ${ }^{40} \mathrm{~K}$, respectively (UNSCEAR, 2000).

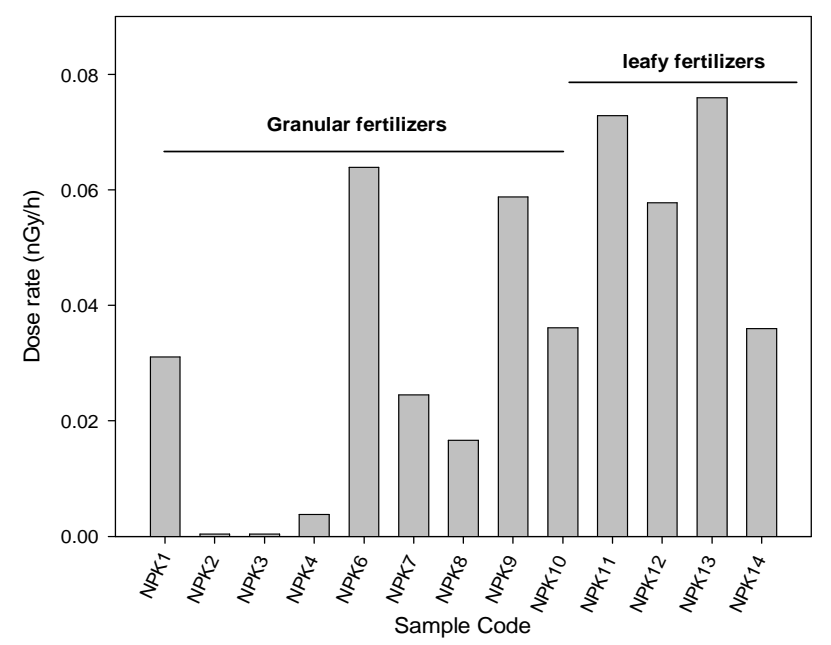

Figure 3 - Absorbed dose rate $1 \mathrm{~m}$ above the ground surface (nGy/h) originated from NPK fertilizers agricultural applications. 


\section{CONCLUSION}

From the results, it could be concluded that.

1. From the viewpoint of biological effect of radiation, the urea fertilizers did not cause any effect on human health.

2 . The high content of uranium radionuclide in the Iraqi granular NPK fertilizer must be taken into account.

3. The main reason for the high radioactivity in the leafy fertilizers was ${ }^{40} \mathrm{~K}$.

4. In spite of the high specific activity of some nuclei in chemical fertilizer, the radium equivalent activity values were within the worldwide average.

5. Chemical fertilizers caused increase in annual exposure dose by no more than $0.15 \%$ which should be taken into account at the continuing use of chemical fertilizers.

\section{REFERENCES}

Becegato, V.A., Ferreira, F.J.F., Machado,W.C.P. (2008), Concentration of radioactive elements (U, Th and $\mathrm{K}$ ) derived from phosphatic fertilizers in cultivated soils. Braz. Arch. Biol. Technol., 51 (6), 1255-1266.

Beretka, J., Matthew, P.J. (1985), Natural radioactivity of Australian building materials, industrial wastes and by-products. Health Phys., 48 (1), 87-95.

Bhatti, T.M., and Malik, K.A. (1994), Phosphate Fertilizers a Potential Source for Uranium Recovery as by-Product., National Institute for Biotechnology and Genetic Engineering (NIBGE) Faisalabad, Technical Report No. PAEC/NIBGE-2.

Conceição, F.T., Bonotto, D.M. (2006), Radionuclides, heavy metals and fluorine incidence at Tapira phosphate rocks, Brazil, and their industrial (by) products. Environ. Pollut., 139 (2), 232-243.

Diab, H.M., Nouh, S.A., Hamdy, A., El-Fiki, S.A. (2008), Evaluation of natural radioactivity in a cultivated area around a fertilizer factory. J. Nucl. Radiat. Phys., 3 (1), 53-62.

El-Zakla, T., Abdel-Ghny, H.A., Hassan, A.M. (2007), Natural radioactivity of some local fertilizers. Rom. J. Phys., 52 (5-7), 731-739.
Ghosh, D., Deb, A., Bera, S., Sengupta, R., Patra, K.K. (2008), Measurement of natural radioactivity in chemical fertilizer and agricultural soil: evidence of high alpha activity. Environ. Geochem. Health, 30 (1), 79-86.

Hamby, D.M., Tynybekov, A.K. (2002), Uranium, Thorium, and Potassium in Soils Along the Shore of Lake Issyk-Kyol in the Kyrghyz Republic. Environ. Monit. Assess., 73 (2), 101-108.

IAEA, (1973), Safe Handling of Radionuclides. Safety Series. No.1, International Atomic Energy Agency, Vienna.

Lambert, R., Grant, C., Sauve, C. (2007), Cadmium and zinc in soil solution extracts following the application of phosphate fertilizers. Sci. Total Environ., 378, 293-305.

Pfister, H., Philipp, G., Pauly, H. (1976), Population dose from natural radionuclides in phosphate fertilizers. Radiat. Environ. Biophys., 13 (3), 247261.

Scholten, L.C., Timmermans, C.W.M. (1996), Natural radioactivity in phosphate fertilizers. Fertil. Res., 43, 103-107.

Singh, J., Singh, H., Singh, S., Bajwa, B.S., Sonkawade, R.G. (2009), Comparative study of natural radioactivity levels in soil samples from the Upper Siwaliks and Punjab, India using gamma-ray spectrometry. J. Environ. Radioactiv., 100, 94-98.

Vassas, C., Pourcelot, L., Vella, C., Carpéna, J., Pupin, J.P., Bouisset, P., Guillot, L. (2006), Mechanisms of enrichment of natural radioactivity along the beaches of the Camargue, France. J. Environ. Radioactiv., 91 (3), 146-159.

UNSCEAR, (1983), Exposure from Natural Sources. United Nations Scientific Committee on the Effects of Atomic Radiation. Report to General Assembly, United Nations, New York.

UNSCEAR, (1993), Sources and Effects of Ionizing Radiation. United Nations Scientific Committee on the Effects of Atomic Radiation. Report to General Assembly, United Nations, New York.

UNSCEAR, (2000), Exposure from Natural Sources. United Nations Scientific Committee on the Effects of Atomic Radiation. Report to General Assembly, United Nations, New York. 